\title{
Entrevista com Gilvan Samico
}

\author{
FABIO FONSECA
}

Fabio Fonseca é docente do curso de Artes Visuais da Universidade Federal de Uberlândia (UFU), na subárea de Desenho. Doutor em Teoria e História da Arte pela Universidade de Brasília (UnB), com período sanduíche no Centro de Linguística da Universidade de Lisboa. Mestre em Teoria e História da Arte pela UnB. Especialista em História da Arte do Século XX e Bacharel em Gravura pela Escola de Música e Belas Artes do Paraná (EMBAP-PR). Atualmente desenvolve sua pesquisa sobre o processo de sobrevivência das imagens, procurando integrar sob um viés teórico-metodológico, a pesquisa em Teoria e História da Arte com a produção prática em Artes. https://orcid.org/0000-0002-1371-5502

Filiação: Universidade Federal de Uberlândia UFU Brasil

ouvirouver Uberlândia v. 15 n. 2 p. 620-633 jul. | dez. 2019 


\section{- RESUMO}

Entrevista com o xilogravador pernambucano Gilvan José Meira Lins Samico. A entrevista aconteceu em setembro de 2010, no agradável sobrado próximo ao Mosteiro de São Bento, no centro de Olinda, onde ele vivia e mantinha seu ateliê, e onde fui recebido de maneira hospitaleira e calorosa por Samico e sua esposa Célida. Após um primeiro dia no qual houve uma conversa, a entrevista foi gravada nos dois dias seguintes. Fiz perguntas referentes à minha pesquisa, mas procurei deixá-lo falar espontaneamente. A entrevista apresenta um panorama, pelo próprio artista, sobre sua trajetória, desde o início no Ateliê Coletivo de Gravura da Sociedade de Arte Moderna do Recife, seu aprendizado com Lívio Abramo na Escola de Artesanato do Museu de Arte Moderna de São Paulo, e Oswaldo Goeldi na Escola Nacional de Belas Artes, no Rio de Janeiro, até o período no qual viveu em Madrid. O artista também fala sobre questões técnicas, suas relações com o mercado de arte e algumas lembranças da infância.

\section{PALAVRAS-CHAVE}

Gilvan Samico; Xilogravura; Gravura.

\section{ABSTRACT}

Interview with the woodcutter Gilvan José Meira Lins Samico. The interview took place on September 2010, at the agreeable loft, next to the São Bento Monastery, downtown Olinda, in which he lived and kept his atelier, and where I was hosted in a hospitable and warm manner by Samico and his wife Célida. After the first day, in which we talked, the interview was recorded in the next two days. I have made questions regarding the topics of my research, but at the same time I have tried to leave him space to speak spontaneously. The interview introduces an overview by the artist himself on his career, from the beginning at the Ateliê Coletivo de Gravura da Sociedade de Arte Moderna do Recife, his apprenticeship with Lívio Abramo at the Escola de Artesanato do Museu de Arte Moderna de São Paulo, and with Oswald Goeldi at the Escola Nacional de Belas Artes, in Rio de Janeiro, up until the time he lived in Madrid. The artist also speaks about technical issues, his relationship with the art market and some memories from his childhood.

\section{KEYWORDS}

Gilvan Samico; Woodcut; Engraving. 


\section{Introdução}

A obra do xilogravador pernambucano Gilvan Samico transita, de maneira marcante, entre o regional e o global, entre o erudito e o popular. Suas gravuras construídas por refinadas texturas em composições minuciosamente bem planejadas, apresentam temas mitológicos, assim como temas da literatura oral dos poetas populares nordestinos, colocada por escrito nos folhetos de cordel. Além de sua terra natal, viveu em São Paulo, Rio de Janeiro e Madrid. Esse trânsito territorial, do qual acumulou lembranças, o sensibilizou e contribuiu com a construção de sua formação artística e poética. Suas paisagens mentais, povoadas por seres mitológicos, refletem a sobreposição das formas e sentidos guardados em sua memória, como fragmentos de sua realidade.

A partir dos anos 1960 suas gravuras começaram a ter como referência os temas da literatura cordel. Passou da representação do ambiente natural para colocar seu imaginário nas gravuras. Procedeu a uma inversão no modo de gravar a madeira. Inicialmente suas gravuras eram escuras e construídas com linhas brancas, então passou a construí-las delimitando o contorno dos objetos com uma linha preta, desbastando na madeira a parte externa e interna das figuras, mantendo apenas a linha de contorno como superfície que recebe a tinta. Também reduziu ao mínimo os elementos da composição. As imagens, despojadas dos detalhes, se tornaram claras e iluminadas. A cor branca deixou de se limitar às linhas e pequenas áreas de luz e passou a ocupar a superfície da gravura.

\section{Samico e a gravura, questões técnicas}

Fabio - Samico, como é o seu trabalho em relação à técnica. Como você faz o tratamento da madeira? É você quem escolhe?

Samico - Não são todos os gravadores que fazem isso, geralmente tem uma pessoa para fazer, mas eu compro a madeira no armazém, ela praticamente bruta, já cortada em prancha, às vezes em tábua; e sou eu que faço a planagem, o acabamento na lixa e a junção de uma tábua com a outra, por causa da dimensão da largura das minhas gravuras que se tornam difícil encontrar uma madeira já assim com mais de 55 centímetros de largura. E, ainda mais, complica por que eu não gravo em qualquer madeira, ela tem que ter uma característica única, a fibra bem fina, fina e uma certa dureza. Eu não gravo em madeira mole. Gosto de sofrer.

Esse trabalho eu faço. Tenho uma pequena oficina no quintal da minha casa e quando precisa eu vou, ou faço uma só ou aproveito, faço duas, três para não estar frequentemente tendo que descer para oficina.

F - Você usa instrumentos? Instrumento de desenho? Compasso, régua...

$\mathrm{S}$ - Eu uso. Eu nem usava por que não precisava, mas hoje a minha gravura tem um caráter mais geométrico das compartimentações. Então, quando eu quero fazer uma circunferência eu vou para o compasso. O gesto puro e essa tal geometria que tem um nome: é geometria sensível, que é feito à mão livre. Não, eu vou para o compasso e faço com régua, compasso, o que precisar.

$$
\begin{aligned}
& \mathrm{F} \text { - É você mesmo que imprime? } \\
& \mathrm{S} \text { - Sou eu mesmo. }
\end{aligned}
$$


F - Você usa um lado da matriz preta e o outro lado você coloca todas as cores?

$S$ - É uma regra mais ou menos geral. Nos últimos tempos, depois que comecei a fazer essas gravuras grandes, só uma vez eu precisei fazer uma outra matriz para uma só impressão, uma única cor.

Todas as ocasiões, mesmo onde aparece justaposição, onde eu tenho uma cor perto da outra, eu uso o artifício de entintar um lado, uma parte, limpar o que sobrou, imprimir e depois fazer isso mesmo na outra cor que está justaposta. $E$ isso simplifica tudo. E mesmo por que não é todo mundo, todos os gravadores que usam cor e que podem fazer isso, por que eu tenho, às vezes, essa justaposição, mas superposição dificilmente. Às vezes, eu faço superposições, mas usando, por exemplo: ultimamente eu fiz uma gravura que tem meio sol, não é? Aí ele vem numa gradação de vermelho, de verde e amarelo para vermelho e eu vou imprimindo por parte. Imprimo uma cor só, quer dizer a cor mais clara, depois uma mais escura, e depois uma marrom, todas uma sobre a outra. Entendeu?

F - Entendi.

S - Mas, isso é um artifício. Já fiz também a impressão parte numa matriz só, numa matriz do preto. Às vezes, só com a matriz do preto, como Goeldi passou a fazer no fim, um pouco antes de morrer, ele estava dispensando a segunda matriz, a segunda, a terceira e tal.

Mas era um trabalho de chinês. Eu errava de vez em quando, por que me esquecia de limpar a cor. E quando se faz isso você tem tinta numa área que pertence ao preto, não é? Mas aí você não vai usar o preto ali, faz o entintamento, limpa tudo o que sobrou, imprime, outra área também. Uma coisa parecida com o que eu faço, mas numa matriz só.

Mas, às vezes a gente esquece de limpar, quando vai imprimir o preto e aí, quando vê o preto: pá, em cima da cor! Desisti disso. E era muito complicado, muito complicada essa limpeza. Se eu fiz? Eu fiz sim, mas não quero mais fazer.

$\mathrm{F}$ - Você tem explorado outras técnicas; pintura, litogravura?

S - É. Mas tudo com a contensão. Por exemplo, no caso da pintura, eu, como em outras conversas que nós tivemos, eu nunca pensei em ser gravador. Eu pensei em fazer uma gravura, assim, esporadicamente e tal, mas aconteceu da gravura me pegar, não é? Quer dizer, eu não sei se você vai fazer, aí não, mas em outra sessão alguma pergunta envolvendo mais, sei lá, a minha história como, não sei.

\section{O ateliê coletivo de gravura e a partida de Pernambuco}

S - Eu não era pintor, eu era um aprendiz de pintor quando comecei a fazer gravura por um acaso. Posso até explicar o acaso qual foi. Vá lá.

$\mathrm{F}$ - Por favor.

S - Eu fiz parte de um ateliê coletivo. Isso está dito por aí, talvez você já tenha até lido.

F - Já.

S - Havia já uns antecedentes de clube de gravura principalmente no Rio Grande do Sul. Então o Abelardo da Hora achou que devia criar lá dentro do ateliê coletivo um clube de gravura também, porque isso movimentaria o ateliê, e também seria uma tentativa de angariar algum dinheiro para compra de material, pagamento do aluguel do ateliê e tudo o mais. 
Então, como mais ou menos acontece, cada participante abre uma matriz. E aí eu não sei se fui o primeiro, segundo ou terceiro, não me lembro mais, sei que eu fiz a minha primeira gravura, não chegou nem a ser uma xilogravura, foi uma gravura feita em gesso, numa placa de gesso.

$\mathrm{F}$ - Era Pescadores?

$S$ - É. Pescadores.

Fiz essa gravura. O gesso foi uma decepção para mim, fiz, mas não tive vontade de fazer mais nenhuma. Então, o que eu fazia? Eu não ia todo dia para o ateliê, aparecia lá, fazia uma besteira, mas ficava muitas vezes em casa. Então, comecei a pegar madeira, a comprar a madeira, preparar a matriz e gravar em madeira. Foi assim que eu comecei a virar gravador.

Em determinado momento, isso em 1957, já fazia uns cinco anos que o ateliê existia, eu resolvi dar uma saída para, tem vários motivos, mas o principal é que eu queria ver outras coisas. No caso, eu conhecia São Paulo, já tinha passado pelo Rio e tal, mas coisa de visita, não é? Nessa vez eu fui passar pelo menos três meses em São Paulo. Eu sei que desse mês acabei passando sete anos, não em São Paulo, em São Paulo foi um tempo que eu devo ter passado, uns seis meses mais ou menos.

Então, a minha história, ao anunciar que eu ia pra São Paulo, alguém como Aloísio Magalhães tomou conhecimento disso. Houve um pouco antes naquela época um salão no Museu do Estado, aqui de Pernambuco, que eu participei com uma gravura, que era uma coisa que não aparecia.

Aloísio tinha sido membro do júri, viu uma gravura minha e chegaram a me premiar. Bom, eu ainda acho, digo com uma certa brincadeira, mas sei lá, mas com alguma porcentagem de verdade também, por que eu perguntava pelo salão e não tinha ninguém com gravura. No primeiro salão eu mandei, eu acho que não tinha ninguém na sessão de gravura e cada uma lá tinha um prêmio - pintura, escultura, desenho, gravura e não sei mais o quê. Então, o único que tinha era eu, e me deram o prêmio. (risos)

\section{São Paulo e o aprendizado com Lívio Abramo}

S - Mas aí, eu anunciei essa coisa quando Aloísio me encontrou na rua e disse: "Samico, alguém me disse que você está indo para São Paulo". Eu digo: "Bom, não sei se é para São Paulo, eu vou à São Paulo, não sei que tempo eu vou ficar". Ele disse: "E o que é que você vai fazer lá?" Eu digo: "Praticamente, nada. Vou mudar um pouco de lugar, de clima". Aí ele disse: "Você não está fazendo gravura? Eu não lhe dei um prêmio?" Eu digo: "Ah, é verdade. Eu estou fazendo gravura devagarinho". Ele disse: "Eu sou muito amigo de Lívio Abramo. Você quer uma apresentação para Lívio Abramo? Você podia ter algum contato com ele, é uma figura ótima". Aí eu digo: "Bom, quero". Eu com esse "quero" que eu estou dizendo agora, eu já fiz muita brincadeira, por que eu digo: Eu virei gravador por ter dito não sei quantos "quero". E ao longo da história que eu estou contando vai aparecer como.

Então, eu fui embora para São Paulo com um bilhetezinho dele me apresentando a Lívio. Chego no Jornal onde o Lívio trabalhava, pedi para falar com ele. 
Falei, me apresentei, mostrei o bilhetinho de Aloísio, ele abriu e disse: "Ah, que ótimo! Eu estou ensinando na escola de artesanato do Museu de Arte Moderna de São Paulo. Eu posso tentar uma bolsa, você quer?" Eu digo: "Quero". Olha o "quero", segundo "quero", não é? Ocorreu assim: "Eu não quero nem saber se eu quero, eu me jogo aí dentro!". Então, lá fomos nós, no primeiro dia após a minha chegada. Conheci toda a turma de lá, e ele tinha vários alunos, inclusive gente que está lá já em São Paulo. Bom; de gravador mesmo pouca gente ficou, que eu tenha conhecimento.

Mas tinha, por exemplo, Antônio Henrique Amaral era da turma que eu frequentei, eu me lembro dele lá. Tinha outros, João da Mata e tinham várias mulheres, jovens, fazendo gravura lá. E tinha uma figura chamada Dorothy Bastos, que já fazia gravura de topo como o Lívio fazia. Funcionava lá dentro como se fosse uma monitora.

Então, era um lugar bastante agradável. Agora o desagradável era eu por que era muito calado, muito fechado. E um dia, até uma coisa engraçada, Lívio grita de lá: "Samico, por que é que você está fazendo gravura no escuro?" Eu tinha saído da mesa e fiquei em pé em um armário gravando e ele disse que eu estava fazendo gravura no escuro!

Então fiquei lá um tempo. Um mês depois, eu acho que era fim de ano, a escola entrou de férias. Aí eu fiquei por ali fazendo minha gravura dentro de um quarto de pensão e tal. Depois, encontrei um amigo que era daqui, que era desses que frequentam a casa da gente. E ele sabia que eu tinha ido para lá, me procurou e a gente se encontrou e ele disse: "Olha, eu estou aqui num determinado lugar, mas quero alugar um quarto por aí num pardieiro desses". Tinham muitos em São Paulo, não sei, eu acho que não tem mais não. Não tinham aquelas ruas mais ou menos por ali em torno da Avenida São João.

Só sei que a gente acabou ficando. Eu saí da pensão e fui morar nesse quarto num pardieiro junto com ele. Ele era um camarada que estava trabalhando, não sei se em comércio, não me lembro mais. Ele saia e eu ficava eu lá o tempo livre que tinha gravando durante todo o tempo de férias.

Depois a escola reabriu e eu voltei, naturalmente. Eu fiquei mais um tempo, acho que já ia uns três meses ou mais. E aí começou aquela coisa que todo mundo precisa, não é? Ganhar dinheiro. Eu tinha deixado um emprego aqui, deixado não, eu me licenciei sem vencimento e fui pra lá. Não tinha fonte de renda. Eu tinha levado algum dinheiro, mas precisava... E de onde se tira e não se bota, geralmente se acaba.

Eu tinha um primo que morava no Rio de Janeiro que me encontrou lá e disse: "Olha, vá para o Rio, porque eu estou lá e é mais fácil eu Ihe ajudar a encontrar qualquer coisa para você fazer, para ganhar dinheiro". Bom, aí foi uma pena, por que eu tive me despedir de lá, do pessoal de São Paulo, de Lívio e tal. Mas aconteceu outra coisa, um outro "quero". Ele antecipou-se e me ofereceu uma apresentação para Goeldi, para Oswaldo Goeldi e eu aceitei. Ele disse: "Você vai para o Rio, eu sou muito amigo de Goeldi. Você quer uma apresentação para ele? Ele ensina lá um curso livre". Eu digo: "Quero". Aí, outro "quero". 


\section{Rio de Janeiro, a experiência com Goeldi, os salões e o design}

S - Cheguei no Rio fui procurar Goeldi. Lá era curioso, por que eu não me lembro de ter feito uma só gravura no curso dele. Eu ia muito pra ver quem estava fazendo e ter algum tipo de conversa com ele mesmo, com Goeldi. Não sei, preferia, não sei se por inibição, não sei por que, mas eu fiz isso. Então, via o pessoal trabalhando.

Não! Fiz uma pequena gravura em metal, uma coisinha miúda e só. Perdi a matriz, acho que ficou por lá. E eu tenho um único exemplar. Não foi feito tiragem.

Pois bem, então é essa coisa: eu cheguei nesse ponto para dizer, que com tantos "quero fazer gravura"... Não tem espaço também, porque gravura eu fazia num cantinho lá, xilogravura você imprime, não precisa... Eu não tinha prensa, como até hoje não tenho. Não tinha prensa, imprimia na colher, como se fazia. Aliás, lá na Escola de Artesanato, em São Paulo ninguém imprimia com prensa, nem xilogravura, nem linóleo. Quer dizer, fiz alguns linóleos, porque Lívio preferia, ofereceu um pedaço de linóleo a ter um serrote, ter madeira para serrar esse negócio. Então, a gente trabalhava com linóleo, que a diferença é só por que o linóleo é mais mole e corta bem para tudo quanto é lado. Mas eu fazia no meu reduto, lá no lugar onde eu vivia eu fazia na madeira. Linóleo ficava somente para a Escola.

Pois bem, no Rio eu fazia gravura num quarto que meu primo me deu pra dormir, lá mesmo eu fazia. Tudo era muito pequeno, quer dizer, a gravura era pequena. Mas eu fiz algumas gravuras que foram para salóes e fiz lá dentro do quarto que ele destinou para mim.

Então, isso acrescentou, por que no momento que você manda para um salão, é aceito, essa coisa vai Ihe dando... Não é? Poxa! Você ser aceito num Salão Nacional de Arte!

Então, aí fui ganhando prêmio. Ganhei o Prêmio de Menção de Júri. Não. Primeiro um prêmio de aquisição dentro do Salão, depois, um ano ou dois anos esse, depois o Prêmio de Viajem no País.

Fiquei, todo Salão que tinha, eu mandava. Acontece que isso já era nos anos 60, eu cheguei lá em fim de 58. Aí no Rio eu casei e a gente teve dois filhos. Mas um pouco antes disso, estou no Rio trabalhando num escritório de arquitetura, fazendo planta, copiando, fazendo coisas de eletricidade, eu não tinha muita formação. Eu já tinha trabalhado aqui em Pernambuco numa repartição como desenhista de arquitetura e lá no Rio era o lugar que eu ia, para onde eu ia procurar uma coisa de salário mínimo para ficar.

Passei por alguns escritórios de lá, alguns que faziam projeto de instalação elétrica, hidráulica. Minha função era pegar o rascunho que o arquiteto fazia, botar papel em cima e desenhar à tinta, nada de mais, tudo só para ganhar aquele trocado. E aí fui ficando.

Mais tarde, encontro Aloísio Magalhães lá no Rio de Janeiro, que já tinha me dito num encontro que nós tivemos em São Paulo que ia abrir no Rio, estava só esperando a hora certa, um escritório para fazer comunicação visual. Bom, aí fui me embora para o Rio e tenho esse encontro com ele. Ele disse: "Ah, olha, eu já estou montado lá num galpão dos fotógrafos". E aí: "Você quer ir trabalhar um expediente comigo lá? Por que eu não tenho ninguém ainda para essa parte de desenho". 
"Quero". Quer dizer, esse "quero" não foi mais ligado à gravura, mas eu já estava por ali, como já lhe disse, já ganhando o prêmio de salão, esse negócio todo. Aí eu trabalhava de manhã num escritório de arquitetura e de tarde ia... Chegou um ponto que eu larguei o escritório de arquitetura e fiquei com ele. Houve uma transição, porque ele saiu desse galpão e depois foi para o Leme, lá na parte alta do Leme e eu fui com ele.

Aí tinha o negócio de eu ter filho e tudo mais, lá um dia, me deu aquele negócio, estava sempre pensando em voltar para cá, sempre pensando, Aloísio viajou para os Estados Unidos e me deu aquela agonia, cheguei em casa e eu disse: "MuIher, vamos voltar para o Nordeste". Ela é da Paraíba. Aí ela disse: "Vamos". Pronto, foi a conta. Quinze dias depois a gente estava dentro dum navio vindo para cá.

\section{O retorno à Pernambuco como gravador}

S - Aí chega eu aqui gravador, está entendendo? Já tinha ganhado outros prêmios no Museu de Pernambuco fazendo gravura, a pintura ficou em segundo plano.

Quer dizer, eu não sei se eu seria pintor, eu não sei. A gente nunca sabe, não é? Eu sempre queria ser pintor. Agora pintor inclusive eu sou. Não sou bom pintor, não é? Isso que é a diferença, por que eu podia fazer as duas coisas, duas coisas eu sei. Mas eu fui, a gravura realmente me tomou. Eu hoje continuo pintando, mas pinto por... Às vezes até os mesmos temas da gravura, tem até um exemplo ali. Não sei se você espiou, porque quem chega aqui não espia para as pinturas não, só expia para as gravuras. É mesmo! Não pergunta nem de quem é.

Então, a história foi essa. A história de gravador, minha história é essa.

A gente tinha escolhido, vindo para cá, tentar morar aqui em Olinda. Viemos, deixamos dois filhos lá com a família e vínhamos quase todos os dias aqui, depois do expediente, que retomei o emprego, tudo mais. A gente vinha ver o que encontrava aqui para comprar, as ruínas. Olinda era muito... Essa parte aqui de cima era muito arruinada, hoje está um pouco menos, por que houve essa invasão. Eu não sou olindense eu sou invasor. Mas aí apareceu, era uma quase ruína, era um arruinado isso aqui.

Aí eu consegui comprar com um preço muito barato, ainda ficar pagando aos pedaços. A gente fez só uma limpeza, bateu uns pedaços de compensados nuns buracos que tinha no assoalho, aí melhorei um banheirinho, botei um fio com algumas lâmpadas, era um negócio muito precário aqui. A casa estava toda dilacerada.

Ficamos vivendo aqui, até que por conta de um amigo, um grande amigo que eu tinha, era dono de uma empresa de construção e me conheceu por causa da minha gravura e também com a contribuição de Aloísio Magalhães. Aloísio tinha feito uma marca de fábrica para ele, um logotipo, então se tornaram amigos e por afinidade, por extensão eu acabei ficando amigo dele por conta das gravuras que ele me comprava. Eu já morava aqui e ele me escreveu, eu já tinha abandonado o Salão e tudo, por que me restava o grande prêmio, o maior prêmio que o Salão dava, que era o Prêmio de Viajem ao Exterior.

Então, eu estava aqui, aliás, passei uns três ou quatro anos, não me lembro, sem fazer uma gravura. Por que é mudança, não é? Essa coisa toda, ficou meio 
atrapalhado.

Depois eu voltei a gravar e ele me inscreveu com três gravuras, escreveu "gravura um, dois e três", por que ele não sabia o nome, me inscreveu lá e mandou, passou um telegrama dizendo que eu estava inscrito no Salão. Aí eu mandei as três gravuras. Eu já tinha, como Ihe disse, a Menção de Júri, já podia mandar sem passar por júri nenhum, já tinha ganhado inclusive o Prêmio de Viajem no País. E então veio esse prêmio em 1968. Eu tinha chegado aqui em 64, você vê que já fazia um bom tempo, não é? Não, eu cheguei em 65. O Golpe Militar foi em 64 e em 65 eu já estava aqui. Fiz gravura do jeito que eu pude aqui dentro. Foram essas gravuras, que eu tinha feito aqui, que mandei para o Salão. Então em 68 me deram o Prêmio de Viajem ao Exterior.

\section{Samico e o mercado de arte}

F - Quantos exemplares você costuma imprimir de suas gravuras?

$\mathrm{S}$ - Atualmente cento e vinte, mais dez por cento, como prova de artista.

Como eu não tenho vínculo nenhum com galeria, quer dizer, já tive mais, com o tempo fui perdendo esse vínculo, por uma questão pessoal, eu quis mesmo isso. Então as minhas gravuras estão aqui à disposição de quem quiser comprar, e o que não é raro. Talvez, até por isso, eu larguei as galerias. Porque tinha uma coisa curiosa, eu percebi depois de algum tempo que a galeria funcionava muito pouco para mim, não é culpa da galeria não, a culpa é minha. Porque é o seguinte, é sabidamente até um tempo desse aí eu fazia uma gravura por ano. Teve ano que eu gravei cinco, seis, mas todas gravuras pequenas, eu acabava uma e começava outra. Com essa coisa bem maior eu não sei, eu me esgotava quando fazia uma gravura e não via necessidade de fazer em seguida outra, para mim bastava isso. Então as galerias querem estar vendendo sempre e eu fazia uma imagem por ano.

Digamos, quando uma galeria me procurasse eu teria dez anos de gravura para oferecer, depois de compradas dez gravuras, teria que ser repetido, as dez gravuras, até que aparecesse a décima primeira. Por conta disso eu ficava tranquilo em casa porque as pessoas vinham comprar essas gravuras, não era um mercado muito ágil. As pessoas compravam e eu juntava com a minha renda de outras coisas e conseguia, e consigo hoje sobreviver dessa forma.

Acontecia que, em dado momento ligava uma galeria de São Paulo, por exemplo, "Samico eu tenho um comprador para uma gravura sua". Tinha decorrido uns quatro ou cinco anos que eu não tinha contato nenhum com galerista nenhum. Então o que acontecia? Ponho a gravura dentro do tubo, dou minha conta bancária e eles botam cinquenta por cento do meu preço na minha conta, quando vendesse. Então não tinha sentido, não me interessava uma coisa dessa forma, de ano em ano, de dois em dois anos eu vender uma gravura através de uma galeria, não dava. Culpa dela? Não, culpa minha. Eu não abastecia constantemente as galerias com peças mais recentes, mais novas. Então eu me acomodei com essa coisa, o comprador me telefona, mando por sedex, vem aqui na minha casa, um compra para o outro, às vezes vem gente de São Paulo, do Rio, de Brasília, vem aqui porque um amigo, uma pessoa da família, pediu que ele comprasse, ao gosto dele uma gravura minha.

Então é assim que eu, há muito tempo, me mantenho. Minhas gravuras são 
adquiridas dessa forma.

F - Qual é o teu público Samico? É nacional? Vêm pessoas de outros países comprar as suas gravuras?

$S$ - Vem, mas não é todo dia, não é com frequência são casos esporádicos. O mais são pessoas daqui, e muito mais que aqui, Rio, São Paulo e Brasília. Podendo ser de vez em quando Belo Horizonte, ou outro estado qualquer, nunca fiz um estudo de incidência de compra de um determinado estado. Olhando assim por cima é Rio e São Paulo, os dois mais frequentes.

$\mathrm{F}$ - Dessas suas gravuras novas, qual é o preço de cada uma delas?

$S$ - Hoje custam dois mil e quinhentos reais só a folha impressa. Se ela for vendida com a moldura, então acrescenta-se, por conta do moldureiro, pois eu não coloco na moldura, quinhentos reais. Então fica tudo por três mil reais.

$\mathrm{F}$ - As suas gravuras têm alguma encomenda, com alguma característica particular, alguma pequena, alguma pintura? Excluindo essas gravuras grandes que você produz.

S - Acontece com pouquíssima frequência. Por exemplo, em toda minha vida de gravador eu só fiz duas coisas assim. Uma para um álbum, que foi um gravador do Rio de Janeiro que coordenou um álbum para uma galeria que não existe mais, que era a galeria Bonino. A outra para o museu da Chácara do Céu, porque eles tinham um programa de encomendar, ainda hoje tem, eles fazem encomenda, a mim não pediram mais, mas eu fiz uma imagem, fiz uma matriz para esse museu. Fiz a tiragem e doei a matriz, porque eles me pediram. Em nenhum dos dois casos me pediram tema, me pediram uma gravura com tal dimensão que era para poder se encaixar na programação deles.

$\mathrm{F}-\mathrm{E}$ as exposições nos museus, ajudam a vender as gravuras?

S - Não há dúvida. A gente não vende lá, exposição de museu não tem essa coisa comercial, mas claro que os galeristas vão ver o que eu tenho feito de mais novo, e algumas pessoas, algumas galerias adquirem particularmente. Isso acontece mais também por lá. Você veja, ultimamente eu só tenho feito exposições em museus, porque qualquer exposição que eu faça com dez gravuras, já é uma retrospectiva, por conta da minha produção. Então uma exposição em um museu, que já é uma retrospectiva, dificilmente um museu faz alguma exposição pequena com alguns trabalhos só, mas no meu caso as exposições são feitas com esse caráter, um caráter retrospectivo.

\section{A memória religiosa da infância}

F - Como foi a sua religiosidade na infância?

$\mathrm{S}$ - la para a missa, obrigado, todo domingo. Fui criado dentro do catolicismo, dentro dessa coisa da ideia de inferno, de Deus, de paraíso, essa coisa toda. $\mathrm{E}$ a ideia do inferno, do demônio, me importunou muito. Até hoje eu tenho uma carga daquela coisa que não chega a ser medo, eu acho que é pavor mesmo (risos). Nem acredito em inferno, mas toda ligação que eu podia fazer com o demoníaco, com o inferno, era por conta da repressão que eu recebia.

Queria gritar, não podia, queria falar um nome feio, não podia. "Cebola", no meu tempo era um motivo para ser repreendido. Compreendo que quando a minha 
mãe me ouvia falar de uma certa forma, agressiva "cebola", enfática, é evidente que ela estava sabendo que eu não queria falar de cebola, eu substituía por "cebola", "danado", todas essas coisas. Dá para entender isso agora, quando eu era criança eu dizia, "mas será possível que dizer cebola é proibido?" Depois eu percebi que tinha essa tradução, feita por ela.

Ela me obrigava a ir todo domingo, mas era um inferno, porque eu ia para a igreja e ficava só espiando a menina que entrava. Entendeu? E aí vinha aquela coisa da repressão. Eu mesmo, achando um absurdo que eu estivesse na igreja desejando uma mulher. Esse tempo que a gente vai descobrindo essas coisas. Então isso acrescentou a ideia do pecado, essa coisa chata. Bom, não vamos discutir, se for puxar a história da Igreja, os pecados são muito maiores do que qualquer um de nós. Então a coisa se passou dessa forma.

Agora, é evidente que deve haver lá dentro de mim, senão eu não faria o que faço, algum elemento que produz essa ideia de divino, da coisa extra Terra sem chegar a essa coisa de céu e inferno.

$\mathrm{F}$ - Mas você acredita em Deus?

S - Como uma energia. O Deus que a igreja botou envelhece, inclusive não é? O Michelangelo botou o Deus com uma barba enorme. Quer dizer, Deus enveIhece? Até onde Ele vai, na velhice Dele? Então essa ideia que tentam incutir na gente é evidente que quando a gente ganha um pouquinho de inteligência sabe que não deve ser assim. Tanto que para mim é um mistério. A morte continua sendo um mistério. Eu acho que eu vou virar poeira de estrela, ou pó mesmo. É bíblico, não é? Tu és pó e ao pó reverterás. Eu vou para a terra, e pronto, na minha cabeça não tem retorno. E até acho difícil acreditar na ressurreição de uma outra forma, ou em uma vida futura, numa reencarnação. Para desconsolo de alguns (risos).

F - Então você não tem uma leitura da Bíblia?

$\mathrm{S}$ - Não, eu conheço coisas isoladas, um salmo, porque eu fui obrigado a ler, por uma circunstância qualquer, uma passagem da Bíblia. Porque coincidiu de ser um tema muito visível em uma determinada época, com o negócio da "Suzana" (a gravura "Suzana no banho"). Ao abordar isso a coisa se complementa, o livro Suzana está dentro da parte que diz respeito ao profeta Daniel. Mas foi muito inexpressivo como informação, só o essencial para fazer a imagem.

\section{A oralidade das poesias de cordel}

$\mathrm{F}$ - Como era a tua relação com o cordel?

S - Geralmente eram os empregados, eram essas pessoas mais populares que fizeram parte da minha infância, porque estavam dentro de casa. Então eu me lembro de um homem, não sei o que ele fazia lá em casa, só sei que ele me contava. Essa história do "Juvenal e o dragão" eu ouvi dele, e assim mesmo, como nós comentamos o nome dos três cachorros, que eu sabia de outro. É Rompe Ferro, Ventania e Provador, eu acho que é Provador ou Trovador, mas não tenho certeza.

F - Imagino que nas diversas edições eles podem usar nomes diferentes.

S - Podem mudar, porque eles são inventivos, e às vezes por uma questão, até mesmo de registrar a sua passagem por ali, inventam uma coisa para ser diferente. 
F - E essa pessoa que contava essas histórias, ele contava em verso?

$S$ - Era, eu não me lembro dele com o cordel na mão, o cordel é muito informativo. O povo que não teve acesso à leitura, eles aprendiam oralmente, a coisa entrava pelo ouvido, e eles repetiam. Ele tinha tanto interesse de saber, porque isso enriquecia. E acabava passando para outros, era essa a função muito importante do cordel.

E o que a igreja fazia também, da quantidade de imagens que tem dentro, isso tinha a função também de mostrar. Porque o negócio do santinho que se fazia, era para divulgar os que eram os importantes da religião que estava sendo professada, divulgada. A ideia do santinho servir como elemento de divulgação, é uma importância da gravura também, da multiplicação de imagens.

$\mathrm{F}$ - Você lembra se ele tocava um violão também?

S - Não. Era só a voz mesmo. Agora, é uma lembrança muito remota, muito vaga, que eu não tenho com precisão. Não consigo me lembrar dele, da imagem dele.

\section{O prêmio de viagem ao exterior}

F - Em tua viagem ao exterior, que tipo de lugares visitou? Eu estou buscando compreender de que maneira o que você chama "arquitetura", entrou na tua obra.

$\mathrm{S}$ - Na realidade eu já saí com isso daqui. A minha viagem não modificou absolutamente nada no meu trabalho de artista. Conheci gente que foi antes de mim, uns voltaram correndo, porque não aguentaram, e outros voltaram mexidos, embolados. Em um país como o nosso, de um tempo para cá é que tem alguns museus, alguma coisa para a gente ver. E ir para um lugar desses, onde se você demonstra algum interesse por alguma coisa, tem uma fartura muito grande, principalmente no campo das artes. Então todo aquele peso, é difícil de aguentar. Eu vi gente que foi para esse prêmio, e vi outros que fizeram uma andança pelo exterior, pela Europa, e que voltaram meio aperreados da vida. Porque é como se tivesse perdido a identidade dele. Uns precisaram de um tempo para se reintegrar no meio da gente, na cultura da gente, mas outros não conseguiram. Artistas que já tinham uma formação, e não aguentaram.

No meu caso eu lembro de uma coisa engraçada. Eu já te falei desse meu amigo que tinha o teu nome. Foi ele que me inscreveu no salão. Eu tinha desistido do salão, vim embora de lá para cá. Tanto que eu cheguei em sessenta e cinco e fui tirar o prêmio em sessenta e oito, três anos depois, por conta da inscrição que ele fez. Me deram esse prêmio e eu nem sabia que salão tinha sido realizado ou não. Houve crises enormes nesse salão, mas chega aqui um telegrama dizendo que eu havia sido escolhido para esse prêmio. Aí gritei para a mulher: "Mulher, apareceu um telegrama dizendo que eu ganhei o prêmio de viagem ao exterior. $\mathrm{O}$ que é que a gente vai fazer?" Aí ela disse: "Arrumar a mala!" Coisa mais lógica. Mas isso ficou como uma anedota, como uma coisa curiosa que aconteceu. Depois eu me repetia quase diariamente vivendo lá "isso não é um prêmio, isso é um castigo". Eu dizia isso, veja só. Pois bem, de tal forma eu me senti deslocado. Eu voltei com um mês de antecedência ainda, mas isso se diluiu. 
O período eram dois anos, mas houve uma pequena modificação quando eu ganhei para poder facilitar a vida do artista. Porque esse prêmio era dado, e a gente sabe a penúria que viviam os artistas no Brasil, o mercado de arte não existia. Então davam o prêmio e a gente tinha que se deslocar, arranjar dinheiro para seu guarda roupa, para mudança de clima. Geralmente ia-se para a Europa, mas tiveram uns que foram para a Argentina, para o Uruguai. Mas de vez em quando eles cruzavam a fronteira e estavam no Brasil, eu acho que iam até em casa.

Bom quem ia para a Europa ficava mais difícil, mais longe. Mas então eu fiquei tão deslocado que dizia isso quase que diariamente. $O$ frio era uma coisa que me incomodava, os pés não tinham jeito de esquentar e por aí vai. E outra coisa era o país, era o sol, era o que eu fazia por aqui. Enfim, fui aguentando, mas saí daqui sabendo que ia para um lugar muito rico em termos de informação, no campo das artes. Fui com um propósito: "não quero ver arte moderna, eu quero só entrar em museus de obras, de coisas antigas, nada de moderno". Hoje tem essa expressão: "contemporâneo". Eu estou aqui eu sou contemporâneo, fazendo meu trabalho e vivendo, no mesmo tempo dos outros, e estou fora do tempo.

F - Eu considero você um artista contemporâneo.

$S$ - Eu sei, mas de uma maneira muito isolada, eu posso estar colaborando. Mas a política que hoje se usa para essas coisas não me inclui. Está entendendo? Eu não tenho mais vez. Quer dizer, eu tenho porque alguém me deu a importância de eu poder pleitear uma exposição em um museu, ou receber um convite. Porque eu, de certa maneira, nunca pleiteei. Eu podia ter um desejo, mas nunca externei esse desejo. Por exemplo, a exposição que eu fiz na Pinacoteca. Eu lá dentro de mim dizia, "mas é danado, um bocado de gente expôs nessa pinacoteca" e eu nem conhecia a Pinacoteca. Para mim era uma coisa tão importante, e um dia fui convidado para fazer.

Essa minha ida para lá, primeiro eu tenho que dizer onde cheguei. Eu escoIhi um lugar onde eu pudesse ter, pelo menos, uma possibilidade de um entendimento melhor, sobre o ponto de vista linguístico. Então escolhi a Espanha, podia ter escolhido Portugal porque eles falam um português muito parecido com o da gente. Mas preferi a Espanha por uma dose de romantismo. Eu tinha uma coisa assim pela Espanha, talvez pelos grandes nomes. Então fomos para lá. A primeira parada o avião nos deixou em Madrid. Não vamos falar dos desmantelos, das dificuldades, mas a gente foi com a recomendação de uma pessoa que era de lá. Essa pessoa ajudou muito a gente.

Fomos, em um primeiro momento, para uma dessas pousadas. Depois a gente conseguiu alugar um apartamento mobiliado, e aí ficamos mais bem instalados. Pudemos passar três meses. Por sorte minha o prédio ficava a uns quinhentos metros do museu do Prado. Saía de casa, às vezes, e passava pelo museu para ver um quadro, depois de ter ido umas vinte vezes. Então eu fazia isso, depois de ter ido de ter cascavilhado tudo, passado por aqueles corredores de arte que ninguém sabe quem fez, mas está lá no museu, porque é coisa que é para museu mesmo, até os grandes mestres que ficaram até hoje na história da arte. E me dava esse luxo de entrar. Tinha uma exposição de Brueghel, eu ia lá para ver um quadrinho pequeno, que era uma Tentação de Santo Antônio. Tinha um peixinho saindo da água, um quadro bem simples, o demônio nem aparecia. Quanto a isso foi ótimo, porque eu já fui com esse propósito. 
De Madrid fomos para Barcelona passando às vezes um dia, uma noite nas cidades que tinham os seus interesses. Se não tinha um museu, tinha uma catedral, uma igreja gótica, uma igreja barroca. E a gente sempre procurava saber o que podia ver ali. Em Barcelona entramos em contato com nosso conterrâneo, o poeta da secura, João Cabral de Melo Neto, que era cônsul em Barcelona. Foi ótimo, fui bem recebido, ficamos muito ligados. E então começamos a ver as coisas em Barcelona, a inacabada catedral de Gaudí, a obra de Gaudí. Eu, que tinha me proposto a não entrar em um museu moderno acabei entrando num. Pelo que eu me lembro era um embrião do Museu Picasso.

Olinda, setembro de 2010.

Recebido em 27/08/2019 - Aprovado em 03/10/2019

Como citar:

Fonseca, Fabio.; (2019). Entrevista com Gilvan Samico. OuvirOUver, 15(2), 620-633.

https://doi.org/10.14393/OUV-v15n2a2019-50281

A revista ouvirOUver está licenciada com uma Licença Creative

Commons Atribuição-NãoComercial 4.0 Internacional. 